\title{
POLÍTICA, JORNALISMO, IDENTIDADE E FUTEBOL: ANÁLISE DAS CRÔNICAS DO JORNAL DOS SPORTS SOBRE A PARTICIPAÇÃO BRASILEIRA NAS COPAS DO MUNDO REALIZADAS NA DÉCADA DE 1950
}

\author{
POLITICS, JOURNALISM, IDENTITY AND SOCCER: ANALYSIS OF \\ THE JORNAL DOS SPORTS'CHRONICLES ABOUT THE BRAZILIAN \\ PARTICIPATION IN THE WORLD CUPS OCCURRED IN THE 1950'S
}

\author{
Ana Flávia Braun Vieira* \\ Miguel Archanjo de Freitas Junior \\ Bruno José Gabriel ${ }^{* * *}$
}

\begin{abstract}
RESUMO
Este trabalho propõe um estudo contextual das crônicas do Jornal dos Sports acerca da atuação da seleção brasileira nas Copas do Mundo de Futebol realizadas na década de 1950. O sentido em analisar o discurso dos cronistas sobre a participação do Brasil nas Copas ocorridas durante a década de 1950 é o de procurar entender como a interseção entre o contexto político nacional, jornalismo, identidade e futebol colaborou na construção discursiva de um imaginário acerca da seleção e da nação. Com esta investigação, que levou em consideração para a análise questões estruturais mais amplas do campo político e midiático tensionadas pela autonomia discursiva dos cronistas, foi possível compreender que a relevância que ainda hoje é dada a uma ou outra participação do selecionado nas Copas realizadas na década de 1950 está, entre outros motivos, relacionada ao imaginário construído por estas crônicas, que produziram sentidos que vem sendo herdados de geração em geração.
\end{abstract}

Palavras-chave: Política. Jornalismo. Jornal dos Sports. Identidade. Futebol.

\begin{abstract}
This paper proposes a contextual study of the Jornal dos Sports' chronicles about the Brazilian Team in the Football World Cups that occurred in the 1950's. The meaning in analyze the chroniclers' speech about the Brasil's participation in the Cups of 1950, 1954 and 1958 is try to understand how the intersection among nacional political context, journalism, identity and soccer collaborated in the discursive construction of a imaginary about the football team and the nation. With this investigation, which took into account for the analysis broader structural issues of the political and media field tensioned by the chroniclers' discursive autonomy, was possible to understand that the relevance which still today is given to a one or another brazilian's football team participation in the Cups realized in the decade of 1950, among others reasons, is related to the imaginary built by these chronicles, which produced meanings that have been inherited from generation to generation.
\end{abstract}

Keywords: Politics. Journalism. Jornal dos Sports. Identity. Soccer.

\footnotetext{
Formada em História, mestre e doutoranda em Ciências Sociais Aplicadas pela Universidade Estadual de Ponta Grossa.

"Doutor em História pela Universidade Federal do Paraná e professor do Programa Stricto Sensu de Ciências Sociais Aplicadas da Universidade Estadual de Ponta Grossa.

${ }^{* * *}$ Formado em Educação Física, mestre e doutorando em Ciências Sociais Aplicadas pela Universidade Estadual de Ponta Grossa.
} 


\section{CONSIDERAÇÕES INICIAIS}

A sociedade brasileira da década de 1950 experimentou inúmeras transformações em sua organização política, econômica e cultural. A redemocratização, a progressiva abertura ao capital estrangeiro, a crescente urbanização e industrialização foram alguns dos fatores que contribuíram para mudanças estruturais no país, marcadas pelo esgotamento de políticas nacionalistas e a emergência do nacional-desenvolvimentismo. Neste período, entre os mandatos de Eurico Gaspar Dutra, Getúlio Vargas, Café Filho e Juscelino Kubitschek, foram realizadas 03 Copas do Mundo de Futebol.

No Brasil a identificação entre a população e o futebol data do início do século XX (RIBEIRO, 2003) e foi sendo incrementada conforme os usos feitos desta atividade, inclusive na esfera política. Como exemplo, é possível citar o projeto nacionalista do governo Vargas, que se utilizou de práticas populares para forjar um núcleo cultural comum, uma identidade una para todos os brasileiros. De acordo com Parada (2007), "diversas instâncias foram mobilizadas, na maioria das vezes com alguma sincronia, nesse esforço de redefinição da nacionalidade" (PARADA, 2007, p.36). Neste sentido, acredita-se que, de maneira interdependente, os campos político, com destaque para a questão identitária, o jornalístico e o futebolístico comungavam e produziam sentidos em relação ao que se entendia sobre o Brasil e o que era ser brasileiro, o papel dos meios de comunicação e a importância do futebol para o sentimento de pertença nacional.

Partindo desse pressuposto, este trabalho propõe um estudo contextual da interseção entre as instâncias supracitadas, observando como foram produzidos os sentidos oriundos desta relação e que colaboraram na formação de um imaginário coletivo acerca da participação brasileira nas Copas do Mundo. Assim, considerando que "o futebol e as conquistas das Copas do Mundo são pontos de referência para a construção de uma história positiva do Brasil" (DaMatta, 1982), optou-se por analisar as crônicas do Jornal dos Sports (JS) sobre a participação brasileira nas Copas do Mundo de Futebol realizadas na década de 1950, articulando as visões de mundo presentes na imaginação criadora do jornalista sobre o futebol em relação ao meio em que estava inserido.
Os cronistas do periódico carioca entendiam que o âmbito futebolístico era um dos poucos elementos da cultura nacional livre da interferência de valores estrangeiros e seria nesta esfera que o país poderia competir em condições de igualdade com as demais nações. Neste sentido, por intermédio das crônicas, foi sendo construído um imaginário de que o Brasil seria, finalmente, reconhecido no cenário mundial quando se tornasse campeão da Copa do Mundo de Futebol. Esta vitória seria representativa do potencial nacional nos diversos âmbitos, para além do esportivo. Assim, por ser livre de influências externas, no futebol seria possível perceber os elementos mais característicos da identidade brasileira ${ }^{1}$.

A questão identitária é presente na documentação aqui analisada, a partir da qual é possível afirmar que os cronistas do $J S$ buscavam apresentar aos seus leitores uma representação ${ }^{2}$ identitária idealizada, influenciando na construção de um imaginário coletivo ${ }^{3}$ que relacionou o pertencimento nacional ao futebol premissa reforçada nos momentos de Copa do Mundo.

De acordo com Barbosa (2007), a construção de um projeto de identidade nacional, iniciado em 1930 e crescente nas décadas seguintes, se valeu de formulações discursivas e ideológicas efetivadas com o auxílio dos periódicos. Enquanto campo de relativa autonomia - porque nele convergem questões estruturais globais e locais que influenciam na capacidade discursiva individual - o jornalismo é mediador entre o acontecimento e a história. Sua eficácia na construção de sentidos está relacionada às convenções de veracidade que contribuem para que seja "acreditado como verídico por antecipação” (BARBOSA, 2007).

\footnotetext{
${ }^{1} \mathrm{O}$ conceito de identidade empregado neste trabalho corrobora com a visão apresentada por Pollak (1992), que o definiu enquanto “... o sentido da imagem de si, para si e para os outros. Isto é, a imagem que uma pessoa adquire ao longo da vida referente a ela própria (...) para ser percebida da maneira como quer ser percebida pelos outros" (POLLAK, 1992). A esta definição é importante acrescentar a ideia de que a identidade pode ser também criada, organizada e sistematizada, não apenas por agentes individuais e instituições, mas também por projetos nacionalistas e desenvolvimentistas.

${ }^{2}$ De acordo com Chartier (1990), “a representação não é uma cópia do real, sua imagem perfeita, espécie de reflexo, mas uma construção feita a partir dele. A representação envolve processos de percepção, identificação, reconhecimento, classificação, legitimação e exclusão. As representações dizem mais do que aquilo que mostram ou enunciam, carregam sentidos ocultos, que construídos social e historicamente, se internalizam no inconsciente coletivo e se apresentam como naturais, dispensando a reflexão" (CHARTIER, 1990, p.38-39). ${ }^{3}$ De acordo com Dürkheim (1989), imaginário coletivo é o "conjunto das crenças e dos sentidos comuns a média de membros de uma mesma sociedade, que forma um sistema determinado com vida própria" (DÜRKHEIM, 1989, p.32).
} 
Aliada a esta questão, a escolha do $J S$ está relacionada ao seu capital no campo esportivo, aos seus cronistas e ao contexto nos quais produziram sentidos. Ademais, além de ter sido um dos primeiros jornais a noticiar o esporte, era produzido no Rio de Janeiro, Capital da República no período aqui analisado. Este fator é significativo tanto em relação ao campo esportivo, quanto ao midiático, afinal, o Rio de Janeiro "era um dos Estados mais importantes na estrutura do futebol brasileiro" (FREITAS JUNIOR, 2009, p.04) e possuía um conglomerado midiático (BARBOSA, 2007) que servia de referente aos meios de comunicação espalhados pelo país.

Somado a este fator, os cronistas, em sua maioria, eram agentes diretamente ligados aos principais órgãos administrativos do futebol brasileiro, o que os proporcionou informações privilegiadas, em comparação aos impressos concorrentes. Entre esses colaboradores, destacam-se: José Lins do Rego, Manuel do Nascimento de Vargas Netto e Nelson Falcão Rodrigues, entre outros. Para Barbosa (2007), os intelectuais dos grupos dirigentes e a imprensa foram fundamentais na orientação do povo e na apresentação de preceitos nacionais.

A opção pelas crônicas, em detrimento de outros gêneros jornalísticos, tem relação com sua característica híbrida. Neste tipo de literatura, o real serve de referência para o escritor, mas nem por isso o que escreve é a realidade. Tratam-se de representações simbólicas sobre a vida, estando contida de valores sociais, culturais e ideológicos que o autor e seu grupo trazem consigo. Assim, seguindo as orientações de Candido (1992), a análise será realizada considerando aspectos autorais e contextuais, relacionando-os.

O índice para a composição do conjunto documental para a análise foi a relação entre futebol e identidade nacional. Isso significa dizer que este artigo não irá explicitar a cronologia dos episódios relativos à participação da seleção brasileira nas Copas de 1950, 1954 e 1958. Serão analisados somente os eventos relacionados pelos cronistas às questões identitárias nacionais. Neste sentido, foram também incorporadas à análise - porque produziram sentidos para a interpretação da atuação brasileira e pertencimento nacional durante as Copas - os escritos sobre campeonatos e amistosos que a seleção participou ao longo da década de 1950.
É fundamental destacar que entre os próprios cronistas haviam contradições, entretanto, seus discursos eram "eivados de valores tradicionais, representados nas crônicas por meio do saudosismo, da paixão, do improviso, do individualismo, da malícia, da ginga, enfim, de atributos que, para os escritores, expressavam a autenticidade do povo brasileiro" (FREITAS JUNIOR, 2009, p.05). Isto significa dizer que, por mais que as posturas entre os cronistas não fossem homogêneas, estes eram cindidos pelos diversos campos dos quais eram produtos e produtores, deixando expressos em seus textos os atributos do povo brasilei$\mathrm{ro}^{4}$. Diante de algumas posturas divergentes, a análise privilegiou os posicionamentos mais recorrentes nas crônicas do $J S$.

\section{IDENTIDADE BRASILEIRA: UMA NOÇÃO CONSTRUÍDA}

Para a compreensão do imaginário construído pelas crônicas esportivas sobre a participação brasileira nas Copas do Mundo na década de 1950 em relação à identidade nacional e o futebol, faz-se necessário um recuo histórico à década de 1930 e aos processos que construíram elementos da identidade brasileira.

Ao estudar os processos que compõem a história do Brasil é possível perceber que foi a partir da década de 1930, sob as orientações do então Presidente da República Getúlio Dornelles Vargas, que a constituição da identidade nacional ganhou impulso (FAUSTO, 2015). Antes de ser uma manifestação genuinamente popular, esta foi cooptada para um projeto político nacionalista. Tal projeto estava pautado na premissa de que indivíduos isolados não formavam uma nação. Assim, sendo o Brasil um país tão grande e de discrepâncias culturais, o grupo político interessado em manter-se no poder entendia ser necessário forjar um núcleo cultural comum, que servisse para a identificação de todos.

Para Ribeiro (2003), a criação de uma identidade para o povo brasileiro foi

um processo ideológico e doutrinário que pressupunha repensar a sociedade como um todo, dando-lhe

\footnotetext{
${ }^{4}$ A este respeito Freitas Junior (2009) escreveu: "tais discursos estavam em consonância com uma cultura política, que buscavam auxiliar a criação de um imaginário desenvolvimentista e modernizador para o Brasil e que tinha a cultura como um dos seus eixos reflexivos centrais" (FREITAS JUNIOR, 2009, p.07).
} 
uma nova fundação. No mesmo movimento que elaboravam o ideário de um passado de crise e de ausência de identidade, davam organicidade à nação definindo elementos como povo e nação (RIBEIRO, 2003, s/p).

Nesse sentido, diversas manifestações culturais populares foram incorporadas ao projeto do governo e incentivadas pelos intelectuais enquanto práticas comuns aos cidadãos como elemento caracterizador da nacionalidade brasileira.

De acordo com Barbosa (2007), este projeto político era centralizador e monolítico. Esta autora afirma que este regime criou "condições favoráveis para a autonomia da sociedade política, instituindo mecanismos para fortalecimento do poder do Estado, aperfeiçoando formas de controle das diferentes esferas da vida social, multiplicando as ações no sentido de se consolidar nacionalmente (BARBOSA, 2007, p.106). Com esta perspectiva, o Estado "não poderia se manter alheio ao fenômeno social que movimentava milhões de brasileiros" (NEGREIROS, 2003, p.128). Assim, ao lado de manifestações musicais, folclóricas e artísticas, o futebol foi utilizado como um fator de coesão nacional ${ }^{5}$.

De acordo com Ribeiro (2003), 'marcados de maneira significativa pela presença de uma massa de europeus que migravam desde o final do século XIX, os primeiros clubes de futebol surgiram no Brasil no início do século XX" (RIBEIRO, 2003, s/p) e este esporte passou a ser bem visto por parte da elite dirigente: para fins políticos os desportos serviriam para atenuar as tensões do momento ${ }^{6}$. Com a popularização deste esporte ao longo das primeiras décadas do século $\mathrm{XX}$, enquanto um fenômeno de massa, o futebol passou a ser entendido como um elemento fundamental "na construção da identidade nacional brasileira, na medida em que foi se transformando numa "paixão nacional", compondo de maneira significativa o mosaico da cultura política nacional" (RIBEIRO, 2003, s/p).

\footnotetext{
${ }^{5}$ Sobre a interseção entre política e futebol neste momento histórico, Negreiros (2003) escreveu que não é possível detectar claramente os usos do futebol nas diferentes esferas do governo para a manutenção da ordem política vigente. Entretanto, afirmou ser perceptível que "o futebol desse período era considerado como colaborador, no sentido de reforçar a ideia de construção de uma identidade nacional" (NEGREIROS, 2003, p.130).

${ }^{6}$ Ribeiro (2003) entende que tais tensões eram oriundas de pressões do capital internacional e dos conflitos pós 1888 e o surgimento de um mercado de trabalho livre.
}

No debate intelectual da década de 1930, do qual destacam-se as considerações de Gilberto Freyre, o futebol servia como exemplo e reforço de preceitos nacionais, especialmente em relação à identidade brasileira pautada na miscigenação (CAPRARO; SANTOS; LISE, 2012, p.03). O caráter híbrido da população brasileira foi abordado nas crônicas esportivas do JS, para "mostrar que a miscigenação criou um tipo de homem que apresentava características fundamentais para que se pudesse obter sucesso nesse esporte, em que as situações poderiam ser resolvidas por meio da malícia, da ginga, da esperteza, da criatividade..." (FREITAS JUNIOR, 2009, p.06). À interpretação de cada autor, elementos da "democracia racial” faziam-se presentes em parte da crônica esportiva. Tais elementos também foram incorporados nos intentos nacionalistas do governo Vargas.

No projeto getulista o esporte era entendido como uma das peças chaves para a transformação do brasileiro e para a superação de dificuldades políticas. Em declarações para João Lyra Filho, Getúlio Vargas ponderou sobre a relação esporte e sociedade: "a paixão desportiva tem poder miraculoso para conciliar até o ânimo dos integralistas com o dos comunistas, ou pelo menos para amortecer transitoriamente suas incompatibilidades ideológicas (...) É preciso coordenar e disciplinar essas forças, que se avigoram a unidade da consciência nacional" (Guterman, 2014, p.71). Para auxiliar nestes intentos, foi criado pelo governo departamento específico para a propaganda e difusão cultural.

No período em que Vargas esteve na presidência os meios de comunicação foram importantes instrumentos para a divulgação das ações governamentais e um veículo de controle social. As transmissões esportivas e os impressos contribuíram para a ampliação de sua abrangência e efeitos entre as camadas populares. De acordo com Guterman (2014),

A criação de mitos e heróis pelo rádio esportivo, $\mathrm{e}$ posteriormente pela imprensa em geral, ajudou a formatar o caráter nacionalista e épico atribuído ao futebol. A seleção brasileira começava a representar a pátria, e o futebol, em geral, era uma robusta manifestação de brasilidade (GUTERMAN, 2014, p.75). 
O aspecto positivo de cidadania presente no futebol ${ }^{7}$ contribuiu para a adesão popular a este esporte e às representações nele envolvidas. Assim, este esporte se transformou em uma forma de afirmação da superioridade nacional e elemento caracterizador da "brasilidade": se em outros aspectos, como políticos e econômicos, os brasileiros sentiam-se inferiores em comparação aos países desenvolvidos da Europa, no futebol era possível demonstrar pujança. Neste sentido, a participação positiva em Copas do Mundo poderia conotar outro capital para o país, visto que internacionalmente e entre as elites locais o Brasil ainda era percebido como um lugar povoado por mestiços de pouca cultura.

Esta associação entre vitória no campo e, por extensão, fora dele, adentrou o imaginário popular e estendeu-se ao longo dos anos, variando de intensidade de acordo com o momento político nacional e as representações deste pelos periódicos, como o Jornal dos Sports.

\section{O JORNAL DOS SPORTS E A CONSTRUÇÃO DE UMA REPRESENTAÇÃO IDENTITÁRIA IDEALIZADA}

Os elementos que compõem as características do "ser brasileiro" são oriundos de um processo de construção de sentidos no espaço social, "que são constantemente organizados e reorganizados tanto interna quanto externamente" (LOPES, 2007, p.140). Tais rearranjos ocorrem por intermédio do contato com diferentes agentes, atribuindo significados à constituição identitária. Portanto, a identidade não é estável ou homogênea. Esta se edifica sob os pilares de uma estrutura política, econômica, social, cultural - e por que não narrativa? -, que também são mutáveis. Desta forma, a formação identitária se dá a partir de rupturas e permanências estruturais tencionadas em relação ao local/grupo/indivíduo.

Nos processos constitutivos identitários, um dos agentes que merece destaque são os periódicos, por sua eficácia na construção de sentidos em relação a outros meios de comunicação de massa, uma vez que, por sua durabilidade material, as narrativas extrapolam o tempo e o espaço de construção. Por este motivo, os impressos podem ser considerados lugares de memória (NORA, 2003) porque servem "não apenas

${ }^{7}$ Para DaMatta (1982), o esporte teria a capacidade de criar um sentimento de igualdade momentânea entre todos os brasileiros. como cristalizador[es] de uma memória nacional, mas onde se pode perceber as dimensões do vivido, que se manifestam a partir de sua forma e de seu conteúdo" (SANTOS, 2002, p.74). Logo, possuem a capacidade de criar memórias a partir do conteúdo selecionado e publicado, interferindo nos processos identitários ${ }^{8}$. Ao mesmo tempo, podem contribuir ao esquecimento quando deixam de narrar determinados episódios ou pela forma como os abordam.

Por este ângulo, entende-se que a importância dos impressos se encontra na produção de representações sobre uma determinada história e uma memória: "ao mediar a relação dos sujeitos com as transformações do seu cotidiano, produzem no âmbito do senso comum sentidos para os processos históricos nos quais esses sujeitos estão inseridos, da mesma forma que participam da constituição das próprias subjetividades" (RIBEIRO; FERREIRA, 2007, p.07).

No campo esportivo, um dos veículos de comunicação que apresentava significativo capital simbólico e que contribuiu na construção de sentidos sobre a identidade nacional relacionada ao futebol foi o Jornal dos Sports. O diário carioca foi um dos primeiros jornais brasileiros destinados somente a noticiar o esporte.

Este periódico "inaugurava uma nova forma de comunicação entre as práticas esportivas e a camada de pessoas da sociedade que cada vez mais ansiava por informações e histórias sobre esporte, saúde e atividades físicas" (COUTO, 2016, p. 110). Sua fundação, no início da década de 1930, coincide com o processo de ampliação dos interesses pelo esporte, inclusive no plano político. Sobre isto Couto (2016) escreveu:

Os esportes, então, tornavam-se um caminho para o fortalecimento desta política ideológica do Estado, tendo em vista sua capacidade de aglutinar elementos nacionalistas com as sensibilidades e interesses emotivos da população, sem falar nas possibilidades de lazer e entretenimento. Desta forma, uma imprensa que pudesse alinhar a ideologia do Estado getulista com a possibilidade de criar uma cobertura diária dos esportes poderia ser um investimento de longo prazo (COUTO, 2016, p. 112).

\footnotetext{
${ }^{8}$ A memória é uma dimensão fundamental da identidade. De acordo com Lopes (2007), "muito do que dizemos de nós mesmo ou do que os outros dizem de nós se constrói a partir de lembranças. Por isso, a memória é um atributo de suma importância" (LOPES, 2007, p.145).
} 
Isto não significa dizer que o que os cronistas escreviam visava apenas atender questões políticas mais amplas. Apesar da linha editorial do $J S$ não ser opositora ao governo, é necessário considerar que seus jornalistas eram brasileiros e que as contradições vivenciadas no tecido intelectual e popular do país também se faziam presentes em seus textos (RIBEIRO, 2012, p.42). Entretanto, este fator não minimiza a colaboração da imprensa na formação do imaginário coletivo sobre o futebol. Para Santos (2012), "a postura desses cronistas era transmitida a todas as camadas da sociedade, reafirmando o esporte como um ponto essencial da identidade do país" (SANTOS, 2012, p.104).

Neste ponto é importante ponderar que se trata da construção de uma representação identitária idealizada por um grupo específico, o que não significa, necessariamente, que todos os brasileiros entendiam a questão da forma que a apresentada pelos cronistas. Entretanto, além de ser um dos poucos periódicos especializados na temática, o $J S$, por se localizar na capital federal, possuía um potencial de influência maior, em comparação com impressos de outras regiões do pais. Ademais, é necessário acrescentar a esta discussão alguns aspectos relativos ao campo jornalístico.

No período aqui analisado o campo jornalístico estava sendo formado, pautado especialmente nos valores de neutralidade, imparcialidade e objetividade. A construção desse processo de credibilidade na exposição dos fatos que o jornal foi ganhando socialmente desde o início do século - a partir das narrativas organizadas pela própria comunidade jornalística - teve sua consolidação por volta da década de 1950. Barbosa (2007) afirma que essa mítica "é fundamental para dar ao campo lugar autônomo e reconhecido, construindo o jornalismo como a única atividade capaz de decifrar o mundo para o leitor" (BARBOSA, 2007, p.150). A esse respeito, Barbosa (2007) citando o trabalho de Ana Paula Goulart Ribeiro (2000, p.08), escreveu:

A modernização gráfica, editorial, linguística e empresarial dos jornais (...) apresenta para a imprensa a instauração de um lugar institucional que lhe permite, a partir de então, enunciar as verdades dos acontecimentos de forma oficializada e se constituir como registro factual por excelência. Para a pesquisadora [Ana Paula Goulart Ribeiro], a partir desse momento, o jornalismo se afirma como fala autori- zada em relação à constituição do real. $\mathrm{O}$ discurso jornalístico se reveste da aura de fidelidade aos fatos, o que lhe confere considerável poder simbólico (BARBOSA, 2007, p.150-151).

Partindo desse pressuposto é possível dizer que o discurso jornalístico fazia entender sua prática como uma representação exata da realidade. Logo, a credibilidade das palavras publicadas nos jornais formava e cristalizava visões sobre o real. Mesmo as crônicas sendo repletas de considerações e opiniões pessoais daqueles que as escreviam, pelo simples fato de terem sido publicadas em um jornal, tinham seu discurso autorizado, aumentando sua capacidade de influenciar na formação do imaginário coletivo em relação ao futebol e pertencimento. Assim, quando os cronistas do $J S$ escreviam sobre futebol, ser brasileiro, o significado das Copas do Mundo e sobre a imagem do Brasil colaboravam à percepção popular em relação aos sentidos da identidade nacional.

Estas escolhas em relação ao que noticiar pertenciam a um pano de fundo nacional comum. Nenhum jornal seria capaz de impor uma visão de mundo aos seus leitores tratando de temas alheios aos mesmos, afinal, é a relação entre texto e contexto que o torna inteligível. A este respeito Melo (2007) escreveu:

o jornalismo possui uma 'relativa autonomia' em relação ao sistema que se insere, já que possui um 'modus operandi' próprio que se superpõe e interage com o sistema. Dessa forma não corremos o risco nem de superestimar o poder da mídia - que é condicionada culturalmente - nem muito menos menosprezamos sua importância - já que possui relativa autonomia no sistema social além de ter uma posição institucionalmente importante e reconhecida nele (MELO, 2007, p.02).

Nesta relação dialética, os cronistas do $J S$ não apenas reproduziam, mas também alimentavam o sistema ideológico e cultural. O que se publicava, apesar de muitas vezes ser lido como um reflexo no espelho, era uma representação, na qual vários fatores interferiam em suas construções discursivas: "Ao produzir um texto, o profissional, ao mesmo tempo, imprime nele algumas marcas pessoais e reproduz modelos já estruturados pela coletividade" (LOPES, 2007, p.140). Assim, se por um lado os cronistas tinham autonomia literária para escrever, por outro estavam inscritos nos limites da linha editorial do jornal, de 
seus pares, da ideologia de seu grupo; nas lógicas do campo futebolístico; e nas estruturas políticas nacionais. Seus escritos eram resultantes deste conjunto.

A título de exemplo é possível citar o uso recorrente de palavras como "nação", "progresso" e "pátria", o que demonstra uma consonância de ideias com a política nacionalista. Segundo Couto (2016), um dos objetivos do periódico era tornar os esportes comerciais. Este intento demonstra a estreita relação entre a busca por legitimidade no campo jornalístico e o reforço aos preceitos políticos nacionalistas vigentes por meio do esporte, com destaque para o futebol. Este, por sua vez, ao ser caracterizado como um elemento da identidade nacional, tem sua importância legitimada pela imprensa e pela política, estabelecendo, assim, uma rede interdependente de fatores que podem ter contribuído para que determinadas representações sobre as Copas do Mundo realizadas na década de 1950 produzam sentidos nos dias atuais.

\section{REPRESENTAÇÕES DAS COPAS DO MUNDO DE FUTEBOL DA DÉCADA DE 1950 NO JORNAL DO SPORTS}

Considerando a história um processo formado por rupturas e permanências, as ações políticas anteriores promovem sentidos em relação as atuais. Assim, as noções identitárias relativas ao futebol formuladas de 1930 a 1945 foram ganhando novas representações, inclusive midiáticas, ao longo do contexto político da década de 1950.

Neste período o espaço da crônica no JS não era restrito à descrição de questões relativas ao futebol, mas os cronistas, ao escrever sobre ele, englobavam debates sobre a sociedade brasileira e pertencimento. Neste sentido, torna-se pertinente a análise dos posicionamentos elementares da crônica do JS ao longo da década de 1950, relacionando-a com o campo político, identitário e futebolístico, observando como esta relação contribuiu na formação de um imaginário acerca da participação brasileira nas Copas do Mundo de Futebol realizadas na década de 1950.

\section{A copa do brasil (1950)}

Entre os anos de 1946 e 1951 Eurico Gaspar Dutra foi Presidente do Brasil. Destaca-se em sua trajetória política a atuação como Ministro da Guerra no Governo de Getúlio Vargas e seu apoio ao golpe de 1937. Por sua vez, contou com o apoio de Vargas quando de sua candidatura à presidência da república, tendo rompido com o mesmo após sua eleição9. De acordo com Fausto (2015), em sua gestão Dutra optou pelo modelo liberal-democrático, apesar de, em alguns pontos, ainda representar a continuidade do modelo corporativo de Vargas, especialmente em relação à organização dos trabalhadores.

Sua postura liberal, aliada à redução da intervenção estatal, colaborou para que a situação econômica do país fosse favorável. A partir de junho de 1947 passou a estimular a produção para o mercado interno, incentivando a industrialização ${ }^{10}$. E foi nesse contexto de otimismo econômico que a sociedade brasileira recebeu a notícia que a Copa do Mundo de Futebol de 1950 seria realizada em casa.

A possibilidade de sediar o evento atende a questões políticas nacionais. Visando intensificar suas relações no mercado internacional, a realização da competição no Brasil foi uma forma de atrair as atenções mundiais para o país. Entretanto, era necessária a criação de toda uma estrutura para receber um evento desta dimensão. Neste sentido, foram iniciados os primeiros debates acerca da construção do estádio que, à época, seria o maior do mundo. No campo jornalístico, a maioria dos cronistas do JS apresentavam-se favoráveis à construção. Entre outras iniciativas visando o apoio popular na empreitada, destacam-se duas campanhas organizadas pelos cronistas Mario Filho e Geraldo Romualdo da Silva ${ }^{11}$ - que buscava construir uma relação entre o estádio e a credibilidade depositada no Brasil.

O próprio processo de construção do estádio foi utilizado enquanto estratégia discursiva na produção de sentimentos nacionais. Os cronistas do $J S$ utilizaram um fato ocorrido durante a construção do Estádio, como exemplo do sentimento patriótico que acompanhava o povo brasileiro. Esse acontecimento foi protagonizado por um operário chamado Alcebíades

\footnotetext{
${ }^{9}$ Disponível em: http://www.fgv.br/cpdoc/acervo/dicionarios/verbete-biografico/dutra-eurico-gaspar. Acessado em: 15.06.2017.

${ }^{10}$ Tendo como referência o ano de 1947, entre 1948 e 1950 o Produto Interno Bruto cresceu, em média, $8 \%$ ano.

${ }^{11}$ A campanha criada a favor da construção do Estádio Municipal contou também com a participação de articulistas de grande capital simbólico, tais como: Manuel do Nascimento Vargas Netto, sobrinho de Getúlio Vargas e presidente da Federação Metropolitana de Futebol do Rio de Janeiro; João Lyra Filho, que naquele momento era presidente do Conselho Nacional dos Desportos (CND) e também Secretário de Finanças do Distrito Federal.
} 
de Souza Filho, que se atirou sobre um botijão de gás para evitar que ele explodisse. Quando questionado sobre o motivo de ter tomado tal atitude, considerada heroica, ele respondeu: "A minha vida valia muito menos do que as outras e o Estádio Municipal muito mais. Francamente pelo estádio eu correria o risco outra vez. O Brasil não pode fazer feio" ${ }^{12}$. Este episódio foi utilizado pelos cronistas favoráveis ao estádio como fato representante do desejo e da união do povo.

Mesmo com as campanhas promovidas por alguns cronistas do $J S$, havia posicionamentos dissonantes. Dadas as condições estruturais do país, Maurício Medeiros escreveu sobre a necessidade de investimentos em saúde e educação ${ }^{13}$, como prioridade em relação à construção do estádio. Em uma de suas crônicas Vargas Netto contrapôs estes argumentos:

[...] o conforto que o estádio vai proporcionar ao torcedor vai diminuir a necessidade da construção de tantos hospitais. [...] Não vamos voltar ao velho slogan de que o Brasil é um vasto hospital. O Brasil não é só isso, pessimistas perniciosos! O Brasil também é graça da juventude, da força dos atletas, da musculatura do trabalho, da malícia de um povo que sabe sorrir dos falsos apóstolos ${ }^{14}$.

As estratégias discursivas utilizadas pelos cronistas pró-estádio apelavam aos sentimentos e reforçavam questões identitárias brasileiras relativas ao estádio. Ou seja, a construção de algo de tamanho relevo seria motivo de orgulho para os brasileiros e para o país, especialmente porque, segundo a crônica esportiva, a realização deste evento de maneira satisfatória poderia significar a primeira vitória no Brasil frente as demais nações. Neste sentido, os cronistas defendiam que somente com o esforço e união de todos os brasileiros seria possível demonstrar ao mundo a realidade brasileira em processo de modernização ${ }^{15}$. Esta ligação entre estádio e povo brasileiro era

\footnotetext{
${ }^{12}$ JORNAL DOS SPORTS. Ato heróico. Rio de Janeiro, 17 de agosto de 1948, p. 03.

${ }^{13}$ MEDEIROS, Maurício. Prioridades do Rio de Janeiro. Jornal dos Sports. Rio de Janeiro, 01 de junho de 1947.

${ }^{14}$ VARGAS NETTO, Manunel do Nascimento. Jornal dos Sports. Rio de Janeiro, 03 de junho de 1947.

${ }^{15}$ Este posicionamento sintetiza a ideia de um recalque brasileiro, especialmente em relação aos países desenvolvidos - algo que não era exclusividade do campo esportivo. Existia uma grande indignação, especialmente por parte dos cronistas esportivos, que não entendiam como os europeus poderiam ignorar um país que apresentava "o melhor futebol do planeta”. É importante lembrar que na década de 1950 o Brasil realizada investimentos em diversas áreas, visando superar o subdesenvolvimento.
}

recorrente no JS. A título de exemplo é possível citar uma crônica de José Lins do Rego, em que descreveu o Estádio Municipal como um "empreendimento de feição e características eminentemente populares"16.

No que tange a identidade brasileira, os cronistas também se demonstravam preocupados com a forma como os europeus percebiam o Brasil, que ainda era visto como um país agrícola, cheio de matas, indígenas e animais. As representações negativas do país feitas por jornalistas correspondentes estrangeiros foram duramente criticadas pelos cronistas esportivos, que ficaram indignados com os relatos, que iam na contramão das aspirações políticas e midiáticas da época. Sobre estas publicações Vargas Netto escreveu: "Nem como ficção presta!"17. Em resposta foi também publicada uma crônica intitulada "As ervas da vitória" 18 , aproveitando a oportunidade para valorizar as riquezas naturais do país.

Os resultados dos jogos eliminatórios e amistosos para a Copa levaram a torcida brasileira a questionar o desempenho nacional. Diante disto, tem-se início uma tentativa do JS em fazer com que o povo/torcida se tornasse símbolo identitário do futebol nacional. $\mathrm{O}$ apelo às emoções, a presença dos sentimentos era recorrente nas crônicas do periódico e atribuíam ares de dramaticidade para os jogos. Mario Pollo (cronista do Jornal dos Sports e chefe da delegação brasileira na Copa de 1950) convocou o torcedor carioca para aplaudir o selecionado, apoiando a equipe nessa hora de necessidade ${ }^{19}$. Busca-se criar um imaginário de que a torcida possuiria parcela de responsabilidade nos resultados dos jogos.

$O$ recurso às paixões da torcida aumentava esta identificação entre a população e o futebol:

os jogadores receberão desde a entrada em campo a manifestação de confiança e apreço (...) Este triunfo tem que ser conquistado pelos jogadores e pelo povo. Em nenhum momento a torcida poderá desassociar-se dos lutadores em campo ${ }^{20}$.

\footnotetext{
${ }^{16}$ JORNAL DOS SPORTS. Cadeiras cativas. Rio de Janeiro, 1 de janeiro de 1950, p.01.

${ }^{17}$ VARGAS NETTO, Manuel do Nascimento. Vitória dupla. Rio de Janeiro: Jornal dos Sports, 4 de julho de 1950, p.05.

${ }^{18}$ JORNAL DOS SPORTS. As ervas da vitória. Rio de Janeiro, 12 de dezembro de 1949.

${ }^{19}$ POLLO, Mario. Unamo-nos todos pelo Brasil. Jornal dos Sports: Rio de Janeiro, 1 de julho de 1950. p.5.

${ }^{20}$ POLLO, Mario. Unamo-nos todos pelo Brasil. Jornal dos Sports: Rio de Janeiro, 1 de julho de 1950. p.5.
} 
A vitória em campo seria também a vitória da população. A participação da torcida seria como uma "alavanca moral no ânimo dos desportivo dos atletas" $" 21$.

A esse respeito, os cronistas do $J S$, cada qual a sua maneira, procuravam demonstrar que havia sido criado um sentimento de união em torno dos jogos da seleção brasileira. Em seus textos eram suplantadas as diferenças culturais e sociais, produzindo efeitos de sentido para a formação de uma nação una, com um traço marcante: a paixão pelo futebol. A este respeito Vargas Netto escreveu: "nessa hora culminante para a nossa trajetória, em todo o Brasil terão os olhos, os ouvidos, os corações, os temores, os sentimentos e os anseios postos em vocês" 22 .

Por este motivo, autoproclamando-se porta voz das massas trabalhadoras, o jornal solicitava aos donos de comércio e indústrias que encerrassem mais cedo as suas atividades, de maneira que o público pudesse prestigiar o jogo do selecionado: "assim sendo, interpretando o pensamento da imensa massa de torcedor do Rio, o Jornal dos Sports, faz um apelo aos poderes competentes (...) para que siga o exemplo do que já foi espontaneamente feito pelo prefeito"23. Mario Filho escreveu que a maciça presença do povo no estádio era a maior prova de que eles acreditavam no Brasil e aproveitou para reforçar seu discurso sobre a relação criada entre a população e o estádio de futebol. Este era visto como um local propício para o encontro de diferentes pessoas, que tinham a possibilidade de vivenciar momentos de democracia, expressando os seus sentimentos autênticos e unidos em torno da expectativa de uma vitória brasileira ${ }^{24}$.

As crônicas publicadas no $J S$ colaboram para a criação de um cenário que contribuiu para o fortalecimento nacionalista. Neste projeto discursivo, o povo era o elemento central, por isso era recorrente a sua presença nas crônicas, bem como eram feitas analogias entre o povo e o estádio ou então entre o homem da arquibancada e o sucesso da seleção. Os autores compreendiam que a autenticidade brasileira estava

\footnotetext{
${ }^{21}$ VARGAS NETTO, Manuel do Nascimento. Traço de união. Jornal dos Sports: Rio de Janeiro, 15 de junho de 1950, p.05.

${ }^{22}$ VARGAS NETTO, Manuel do Nascimento. Está na hora. Jornal dos Sports: rio de Janeiro, 01 de janeiro de 1950, p.05.

${ }^{23}$ RODRIGUES FILHOS, Mario. Este sim foi um triunfo a altura do nome do nosso football. Jornal dos Sports: Rio de Janeiro, 2 de julho de 1950, p.11. ${ }^{24}$ Este potencial unificador dos estádios foi incorporado por Getúlio Vargas, que em 1951 discursou para milhares de pessoas no São Januário, no Rio de Janeiro.
}

presente no povo, o qual aumentava cada vez mais a sua participação nos jogos do selecionado nacional, dando provas de sua identificação com o scratch e com o país. Nas crônicas há relatos sobre torcedores que passaram a utilizar, orgulhosamente, utensílios que simbolizavam a pátria e durante a execução do hino nacional podia-se sentir no estádio lotado um clima de tensão e êxtase da população presente, que proporcionava um belo exemplo de patriotismo ${ }^{25}$.

Em relação ao selecionado, os cronistas relatavam que os jogadores escolhidos para sua composição eram ideais para representar o povo brasileiro, pois apresentavam um futebol alegre e criativo, fazendo o torcedor esquecer-se das diferenças e dificuldades, criando uma crescente onda de otimismo e ufanis$\mathrm{mo}^{26}$. Utilizavam expressões como "espontaneidade", "individualismo", "improviso" e as características decorrentes da miscigenação para descrever o time que representaria o país. Sobre esta articulação entre características do povo brasileiro e o futebol, é importante destacar que os cronistas do JS tentavam criar um imaginário vitorioso, destacando as possíveis qualidades do jogador brasileiro, justificando que o futebol nacional era melhor porque era mais bonito, era plástico, era diferente - posicionamento de Gilberto Freyre na década de 30 e que foi apropriado por cronistas como Nelson Rodrigues.

Além deste clima otimista construído discursivamente, o desempenho deste time de características genuinamente brasileiras ao longo desta Copa do Mundo colaborou à expectativa de vitória, especialmente com a classificação para disputar a final. Sobre isto Mario Rodrigues Filho escreveu: "nunca a capital da República viveu tanto um acontecimento. E um acontecimento que ainda não aconteceu. É a antecipação do vai acontecer que empolgou a cidade de uma forma jamais vista" ${ }^{27}$.

Era o auge do sentimento de pertença nacional e da certeza que o Brasil era tão bom em futebol e nas demais esferas, quanto qualquer país europeu. Entretanto, o que se viu foi "um povo derrotado" 28.

\footnotetext{
${ }^{25}$ JORNAL DOS SPORTS. Milhares de torcedores acompanham a vitória brasileira. Rio de Janeiro, 11 a 13 de julho de 1950.

${ }^{26}$ RODRIGUES FILHO, Mario. O scratch brasileiro. Jornal dos Sports: Rio de Janeiro, 01 de julho de 1950. p.05.

${ }^{27}$ RODRIGUES FILHO, Mario. O match que vale o campeonato do mundo. Jornal dos Sports: Rio de Janeiro, 15 de julho de 1950, p.05.

${ }^{28}$ REGO, José Lins. A derrota. Jornal dos Sports: Rio de Janeiro, 18 de julho de 1950, p.05.
} 
Os "campeões do mundo" ficaram em segundo lugar, perdendo na final para o Uruguai. O sentimento de pertença identitária, o resultado das partidas anteriores e as narrativas organizadas pelos periódicos tinham criado a expectativa de uma goleada na partida decisiva, que não veio. A repercussão da derrota, em casa, entre aqueles que assistiram ao vivo, ouviram pelo rádio e/ou acompanharam pelos jornais foi grande. A confiança em si e no triunfo da nação brasileira via futebol amargou com o sabor da derrota.

Muitos foram os cronistas que escreveram sobre o fracasso do selecionado brasileiro em projetar o país internacionalmente, fosse tentando aliviar a tristeza que se estabelecera diante a uma expectativa alimentada pelos próprios meios de comunicação ou buscando encontrar motivos que justificassem o fracasso ocorrido. De acordo com Guterman (2014), o lance final da derrota foi repetido milhões de vezes desde de então, gravando infeliz disputa no imaginário brasileiro. As analogias feitas pelos cronistas do $J S$ entre desempenho em campo e desempenho nacional, colaboraram para que o episódio fosse profundamente simbólico no que diz respeito à percepção de si da sociedade brasileira.

Esta atuação da seleção no ano de 1950 continuaria a produzir sentidos na Copa do Mundo de 1954, visto que se tornou referente para pensar a atuação em campo e as relações identitárias brasileiras nos anos subsequentes.

\section{A copa da suíça (1954)}

A derrota no mundial de 1950 foi significativa, posto que havia toda uma expectativa, que fora discursivamente organizada, em relação ao significado daquela vitória. Com a derrota, as certezas identitárias do brasileiro foram abaladas. Acredita-se que, entre outros fatores, a opção pelo modelo nacionalista nas eleições de 1950 possa estar relacionada a esta questão. Assim, 48,7\% da população votou em Getúlio Vargas, que prometeu impulsionar a industrialização nacional visando criar um sistema econômico autônomo (FAUSTO, 2015).

No início da década de 1950, foram desenvolvidas medidas objetivando o desenvolvimento econômico. Entre estas é possível destacar o investimento público no sistema de energia e de transportes (FAUSTO, 2015). Entretanto, o Brasil enfrentava dificuldades, especialmente no que diz respeito à inflação, que chegou a 20,8\% em 1953. Assim, o desafio político era o equilíbrio entre questões trabalhistas e a promoção do crescimento. Para Guterman (2014), "o momento brasileiro, de crise econômica e de identidade, favoreceu o populismo de modo decisivo" (GUTERMAN, 2014, p.102).

Esta política de massas não era bem vista pelos liberais, que defendiam menor intervenção do Estado e abertura ao capital estrangeiro. Assim, Carlos Lacerda, do partido de oposição, iniciou uma campanha defendendo a renúncia de Getúlio. Apesar de seus esforços populistas, com o aumento de $100 \%$ do salário mínimo, visando diminuir os impactos da inflação e promover o desenvolvimento de um mercado consumidor interno, e investimentos em infraestrutura e energia, havia no país uma instabilidade conjuntural e "o nacionalismo varguista encontrava no futebol um respaldo ressabiado, incompleto" (GUTERMAN, 2014, p.104).

Diferentemente das expectativas para a Copa realizada em 1950, as certezas em relação aos encaminhamentos nacionais e o sentido da "brasilidade" estavam abalados para a Copa de 1954, realizada na Suíça. Havia um clima de desconfiança, pautado nos resultados futebolísticos e culturais da competição anterior. Entretanto, os cronistas reforçavam a necessidade de uma vitória para curar a chaga aberta há quatro anos ${ }^{29}$.

Neste ponto é importante destacar que o contrato de leitura ${ }^{30}$ entre os cronistas do JS e seus leitores já estava firmado. Assim, antigas noções que relacionavam a identidade brasileira ao futebol foram reiteradas em relação à Copa de 1954, como o caso da relação entre a população e o futebol, em seu papel de torcedora ${ }^{31}$. Entretanto, diferentemente das crônicas escritas em meados de 1950, existia agora um referente recente para pensar o futebol nacional

\footnotetext{
${ }^{29}$ REGO, José Lins do. A revanche. Jornal dos Sports: Rio de Janeiro, 2 de julho de 1952. p.05.

${ }^{30}$ Neste trabalho, o entendimento da noção de contrato de leitura tem pressupostos teóricos em Fausto Neto (2007). Para este autor, "entende-se, aqui, por contratos de leitura, regras, estratégias e 'políticas' de sentidos que organizam os modos de vinculação entre as ofertas e a recepção dos discursos midiáticos e que se formalizam nas práticas textuais, como instâncias que constituem o ponto de vínculo entre produtores e usuários" (FAUSTO NETO, 2007, p. 10). 31 “(...) Uma das razões da paixão pelo football no Brasil é justamente esta, os que não jogam sentem como que substituídos pelos que jogam. A identificação do torcedor com o jogador é completa". RODRIGUES FILHO, Mario. O football brasileiro. Jornal dos Sports: Rio de Janeiro, 12 de novembro de 1953.
} 
e, por extensão, as próprias questões do país. Esta questão pode ser percebida na crônica de José Lins do Rego, quando da participação do selecionado no Pan-Americano de 1952, realizado no Chile:

Embarcaram os nossos rapazes para mais uma competição internacional, de football. Muito temos sofrido nestes embates, com derrotas que muito nos têm sangrado. Às vezes, tudo temos para vencer, e lá vem um impossível qualquer, e vamos ficando para trás. Esperamos que as coisas corram, neste campeonato do Chile, a nosso favor. Tudo temos para vencer. A nossa rapaziada vai com a disposição para vencer. E que nos traga uma vitória para curar daquela chaga que foi o Campeonato do Mundo ${ }^{32}$.

Este fragmento ilustra a tendência dos cronistas do $J S$ em alimentar uma rivalidade entre as seleções brasileira e uruguaia, tendo como referente a derrota na final do Mundial de 1950. Além disto, aborda questões presentes na sociedade, como o desejo de modernizar-se e tornar o Brasil um país desenvolvido. Este sentimento foi alimentado com a vitória neste campeonato, narrado pelos cronistas como uma revanche.

A despeito desta vitória Getúlio Vargas escreveu para os jogadores, parabenizando-os. E a torcida, que vinha sendo estimulada pelas crônicas, foi às ruas para comemorar:

Mais uma vez o povo brasileiro veio às ruas para aclamar os heróis do futebol. As massas vibraram, com entusiasmo, sem limites. Muita gente não tolera football e considera estes entusiasmos como manifestações fúteis. Mas com o espetáculo de anteontem, estes céticos deverão mudar de opinião. [...] anteontem vi o bom povo, nas suas exuberâncias de coração. E os rapazes que tanto fizeram em Santiago bem mereceram as aclamações das massas generosas ${ }^{33}$.

Novamente foram feitas analogias entre o desempenho em campo e as qualidades da população brasileira, contribuindo para o fortalecimento identitário. Neste sentido, a vitória de goleada no primeiro jogo do campeonato Sul-Americano, realizado em 1953 em Lima, foi um contributo. Entretanto, era

${ }^{32}$ REGO, José Lins. A revanche. Jornal dos Sports: Rio de Janeiro, 02 de julho de 1952, p.05.

${ }^{33}$ REGO, José Lins. O Bom povo. Jornal dos Sports: Rio de Janeiro, 27 de abril de 1952, p.05. preciso ficar atento com o "excesso de elogios" 34 . A cada vitória neste campeonato, os cronistas reiteravam a necessidade de não menosprezar os adversários ${ }^{35}$. Sobre essa "cultura do deboche" (FREITAS JUNIOR, 2009), é importante destacar que o brasileiro se sentia superior em relação aos adversários Sul-Americanos. Entretanto, em relação às equipes europeias, que representavam o patamar de desenvolvimento no qual o país almejava chegar, a percepção era outra.

Além da necessidade dos brasileiros encontrarem um equilíbrio entre sentimentos e atitudes, outras questões foram abordadas pela crônica, como o comportamento da comissão no Peru. Publicou-se sobre possíveis desentendimentos entre seus membros e a mudança do local de concentração levantou suspeição em relação aos reais objetivos da equipe: "também aqui não foi bem recebida a notícia da mudança (...) A nossa representação não foi ao Peru fazer turismo e se divertir! Foi representar o Brasil! Obteve a honra e o dever de representa-lo dignamente" 36 .

Este posicionamento permite compreender como era concebida a representação da pátria por meio do futebol: algo nobre. Sobre o papel dos jogadores, Freitas Junior (2009) escreveu: "são tidos como os legítimos representantes dos sonhos, das esperanças e dos desejos das pessoas que ficaram no país torcendo para que eles não fracassassem. Um possível revés do selecionado, significaria um novo fracasso do homem brasileiro - e também do Brasil" (FREITAS JUNIOR, 2009, p. 73). Este tipo de discurso, assim como em momentos anteriores, colaborou para a criação de expectativas em relação a participação do Brasil no Sul-Americano.

A vitória do Brasil contra o Uruguai - com ares de "vingança" - fez com que fossem retomadas possíveis explicações para a derrota do selecionado brasileiro na final da Copa do Mundo de 1950. No entanto, na partida final contra o Paraguai, o selecionado brasileiro não saiu vitorioso. E a partir daí seguiram diversos escritos sobre os motivos que teriam levado à derrota, perpassando especulações sobre o comportamento da delegação ${ }^{37}$.

\footnotetext{
${ }^{34}$ REGO, José Lins. Excesso de elogios. Jornal dos Sports: Rio de Janeiro, 04 de março de 1953, p.05.

${ }^{35}$ VARGAS NETTO, Manuel do Nascimento. Todo adversário merece respeito. Jornal dos Sports: Rio de Janeiro, 13 de março de 1953, p.05.

${ }^{36}$ ZÉ DE SÃO JANUÁRIO. Mudança na concentração. Rio de Janeiro, 08 de março de 1953, p.05.

${ }^{37}$ JORNAL DOS SPORTS. Aimoré é o único responsável. Rio de Janeiro,
} 
Esta derrota aliada a instabilidade política do período, contribuiu para a desconfiança de si, do Brasil enquanto uma nação. Entretanto, Getúlio ainda insistia em seu projeto nacionalista, que havia dado frutos em seus governos anteriores. Em 1954, na despedida do selecionado que partia para o Campeonato Mundial de Futebol na Suíça, declarou: "E não esqueçam que representarão lá fora a habilidade, a força e a resistência de uma raça. Se vencerem, o Brasil será o vitorioso. Se perderem, quem perderá será o Brasil” (GUTERMAN, 2014, p.106).

Preocupados com a possibilidade de um resultado negativo, dada a conjuntura e os resultados oscilantes em campeonatos e amistosos que antecederam a Copa de 1954, muitos cronistas preferiram não se entusiasmar antecipadamente. Vargas Netto escreveu sobre esse posicionamento pessimista, entendendo-o como um aprendizado decorrente da derrota no Mundial anterior ${ }^{38}$. Já Nelson Rodrigues versava sobre a necessidade da valorização do futebol e do país, não devendo sentir-se inferior, nem se deixar tratar como inferiores. Dados os posicionamentos diversos, é possível perceber que existia uma dificuldade em encontrar um meio termo entre o excesso e a falta de confiança. Tal postura demonstra sinais da fragilidade identitária brasileira em relação à representação de si.

Assim, neste momento, o JS adotou uma nova linha discursiva, tendo como referente os diagnósticos da derrota no Maracanã, em 1950. Os cronistas passaram, então, a valorizar a organização e a preparação antecipada do selecionado nacional - em conivência com os ideais modernizadores do país -, uma vez que entendiam ser necessário encontrar um ponto de equilíbrio entre os problemas que estariam afetando o futebol no país ${ }^{39}$. Como uma espécie de apoio, de auxílio à seleção brasileira, optam por deixar de lado o que seria fundamental em sua profissão: o posicionamento crítico $^{40}$.

31 de março de 1953, p. 01 e 04. ZÉ DE SÃO JANUÁRIO. Uma pedrinha na shooteira. Jornal dos Sports: Rio de Janeiro, 03 de abril de 1953, p.02.

${ }^{38}$ VARGAS NETTO, Manuel do Nascimento. Falta de confiança. Jornal dos Sports: Rio de Janeiro, 05 de março de 1953, p.06.

${ }^{39}$ JORNAL DOS SPORTS. Seleção terá um vasto programa de preparação para a Copa da Suíça. Rio de Janeiro, 17 de abril de 1953.p. 01 e 06.

${ }^{40}$ Sobre este acordo realizado entre os cronistas, publicou-se: "Houve gente inclusive que em pleno fervor patriótico quis selar com sangue qualquer documento que surgisse. O que afinal não foi julgado necessário. Não estavam ali homens de palavra? Resolvido então ficou sem sangue e certo, que o scratch estaria isento de críticas. Ainda que a crítica representasse o que ficou salientado, como sempre representou e continuara a representar o principal papel
Entretanto, a preparação na Suíça não ocorreu a contento. Foram realizados poucos jogos preparatórios, com equipes locais. Com o início do campeonato, a crônica, além de dirigir suas atenções aos dirigentes da Confederação Brasileira de Desportos (CBD), versava sobre a nostalgia dos jogadores há tanto tempo longe de sua pátria, reforçando sentimentos identitários nacionais: “[...] o brasileiro no exterior longe da Pátria é um triste sem vontade, um desanimado. Alguns jogadores escrevem 18 cartas por dia $^{41}$ ". Ademais, outros foram os problemas que afetaram a delegação e, segundo os cronistas, foram responsáveis pelo mau desempenho da seleção na competição: desconhecimento do regulamento, ausência de árbitros sul-americanos e um plano conduzido pelos dirigentes da FIFA, que, segundo o periódico, não poderiam permitir uma nova conquista por parte de uma equipe Sul-Americana (o Uruguai havia vencido as edições de 1930 e 1950), o que prejudicaria o futebol europeu ${ }^{42}$.

"Depois do Maracanazo, a derrota, qualquer uma, não era somente a prova de que éramos inferiores ao adversário: como notou o escritor [Lins do Rego], era a prova de que éramos os piores do mundo" (GUTERMAN, 2014, p.106). Logo, com o sexto lugar na Copa da Suíça, após derrota para a Hungria nas quartas de final, as bases identitárias que vinham sendo construídas ancoradas no futebol foram fragilizadas e a reputação do Brasil foi bastante questionada em relação à violência - que supostamente seria um atributo da sociedade brasileira ${ }^{43}$.

O jogo que eliminou o Brasil da competição ficou conhecido como a "Batalha de Berna" (nome da cidade Suíça onde o jogo foi realizado), por este ter sido marcado por muita tensão e jogadas violentas. Sobre esta questão, verificou-se uma tendência dos periódicos nacionais (JS, Gazeta Esportiva, O Cruzeiro e Manchete Esportiva) em defender os brasileiros, relatando que estes não iniciaram os tumultos. No limite, buscou-se demonstrar que foram levados a tal,

\footnotetext{
da imprensa. Mas era necessário um grande sacrifício. Este compromisso foi honrado mesmo diante de apresentações não convincentes" JORNAL DOS SPORTS. O Banquete da vitória. Rio de Janeiro, 09 de março de 1954.

${ }^{41}$ REGO, José Lins. Porque perdemos. Jornal dos Sports: Rio de Janeiro, 10 de julho de 1954, p.05.

${ }^{42}$ RODRIGUES FILHO, Mario. A justiça que se deve fazer aos brasileiros. Jornal dos Sports: Rio de Janeiro, 29 de junho de 1954, p.05.

${ }^{43}$ JORNAL DIÁRIO DE PERNAMBUCO. Um futebol violento. Londres, 28 de junho de 1954.
} 
influenciados por um resultado negativo, decorrente de uma arbitragem tendenciosa e, principalmente, pela necessidade de auxiliar um companheiro, atingido por uma garrafa lançada pelo adversário ${ }^{44}$, que gerou um tumulto em que até os dirigentes acabaram se envolvendo diretamente na briga.

Se até este momento havia uma preocupação com a imagem apresentada do Brasil ao exterior - já que as atitudes na esfera do futebol eram análogas às dos brasileiros em sociedade -, esta tinha sido comprometida internacionalmente. $\mathrm{O}$ desempenho da seleção e todos os episódios relacionados a este, "apontavam que muitos dos problemas sociais brasileiros ainda permaneciam sem solução, ou seja, o país pouco havia caminhado rumo à modernidade" (FREITAS JUNIOR, 2009, p.105).

A derrota de 1954 foi - assim como a de 1950 - reiterada como referente para ações futuras no futebol e na sociedade brasileira. Entretanto, adentrou ao imaginário coletivo de maneira diferente, como "um passado que deve ser redimido, ou, por outra, apagado até o último vestígio"45. A tentativa de esquecer uma segunda derrota do selecionado brasileiro pode estar relacionado ao que Pollak (1992) chamou de memória traumática, que consiste na iniciativa de poupar as próximas gerações de lembranças desagradáveis. Não se tratava de esquecer a derrota em si, mas o que ela representava em relação às questões identitárias brasileiras.

Após a derrota na Suíça, além da crise no campo futebolístico - e, por conseguinte, cultural -, na esfera política os problemas se agravaram: um dos homens de Getúlio armou contra Carlos Lacerda - jornalista e político da UDN que encabeçou a campanha para a renúncia do então Presidente da República. O atentado fracassou, mas contribuiu para o aumento das pressões favoráveis ao desligamento de Vargas do governo federal. Este, por sua vez, tirou sua própria vida em agosto de 1954. O vice Café Filho assumiu a presidência até 1956, quando Juscelino Kubitschek (JK) assumiu o poder.

\footnotetext{
${ }^{44}$ Sobre este episódio o JS publicou: "Puskas arrebentou uma garrafa de leite na cabeça de Pinheiro quando o nosso jogador procurava dizer algo a um jogador húngaro, ele recebeu o revide que merecia. Pinheiro sofreu um ferimento sobre o olho esquerdo" (JORNAL DOS SPORTS. A batalha de Berna. Rio de Janeiro, 29 de junho de 1954. p.07).

${ }^{45}$ RODRIGUES, Nelson Falcão. O Brasil em Lima. Revista Manchete Esportiva, 09 de março de 1957.
}

\section{A copa da suécia (1958)}

Os planos de JK resumiam-se no slogan "50 anos em 05 " e visavam a modernização do país a partir do interior - daí a construção de uma nova capital federal no Planalto Central. Com a promessa de desenvolvimento e ordem, “depois de tensão e conspiração, finalmente parecia começar um período de estabilidade política no Brasil"' (GUTERMAN, 2014, p.113). Economicamente falando, Juscelino seguiu as linhas varguistas de intervenção estatal, mas abrindo o país para investimentos do capital estrangeiro. $\mathrm{O}$ "nacional-desenvolvimentismo" contribuiu para o avanço da atividade econômica, que cresceu anualmente na média de $7 \%$ até 1961 . Este novo cenário contribuiu para a recuperação da autoestima brasileira, atrelada, mais uma vez, ao futebol.

Comungando com os sentidos vigentes, Nelson Rodrigues afirmava que a missão atribuída aos cronistas era "auxiliar para que o brasileiro conseguisse enxergar suas virtudes" ${ }^{46}$, deixando no passado seu complexo de vira-latas. $\mathrm{O}$ autor busca convencer seus leitores, utilizando posicionamentos metafóricos que potencializam a formação de sentidos, que o brasileiro tinha dificuldades em se valorizar. Assim, o autor buscava argumentos que pudessem auxiliar na mudança do estado de espírito do povo, tornando-os outra vez otimistas em relação ao futuro do futebol nacional.

Ao mesmo tempo, as vitórias do Brasil em competições como a Taça Bernardo O’Higgens, reativava a "cultura do deboche", o que levou Nelson Rodrigues a ponderar sobre algumas características do povo brasileiro:

Quando a equipe nacional ganha é porque o adversário é fraco, quando perde é porque somos incompetentes e quando goleia sente-se melhor do que os outros, menosprezando o adversário, esquecendo que cada jogo é uma história única que acontece em situações especiais ${ }^{47}$.

Esta oscilação entre o excesso e a falta de confiança também foi percebida por Nelson Rodrigues durante o campeonato Sul-Americano, que ocorreu em 1956, no Uruguai. Para o autor, isto seria demonstrativo da dificuldade na definição da identidade

\footnotetext{
${ }^{46}$ RODRIGUES, Nelson Falcão. O problema do brasileiro. Jornal Última Hora: Rio de Janeiro, 20 de agosto de 1958. p.07.

${ }^{47}$ RODRIGUES, Nelson Falcão. A gente é que atrapalha. Jornal dos Sports: Rio de Janeiro, 19 de novembro de 1958, p.05.
} 
nacional. Somada a esta situação, as crônicas sobre os problemas organizacionais da seleção eram constantes, a exemplo do envio de um time formado por jogadores gaúchos como representantes do Brasil no Pan-Americano realizado no México.

As estratégias discursivas das crônicas do $J S$ auxiliaram para elevar a autoestima do torcedor para a Copa de 1958. Entretanto, a sombra - constantemente reafirmada pelo próprio $J S$ e outros meios de comunicação - da derrota de 1950, seguida pela de 1954, ainda se fazia presente. A expectativa sobre o campeonato mundial demonstrava-se pessimista. Entretanto, tal qual no plano político, a organização do futebol estava passando por transformações.

No contexto nacional mais amplo havia uma preocupação organizatória, com planejamentos mais delineados - a exemplo da construção planejada da nova capital federal. Em resposta às aspirações vigentes, a Confederação Brasileira de Desporto propôs o Plano Paulo Machado de Carvalho (PPMC) ${ }^{48}$, que traçou diretrizes para um futebol mais coletivo e científico. A despeito das tendências nacionais e das atitudes da CBD, o JS, em 1958, quase não publicou escritos versando sobre o PPMC e os aspectos de um futebol mais coletivo, mas valorizou características do futebol-arte brasileiro - criando mitos em torno de atuações individuais, como as de Garrincha e Pelé. ${ }^{49}$

Ao exaltar o desempenho de um atleta mestiço e outro negro, que jogavam em condições de igualdade ao futebol europeu, o JS enaltecia as "reais virtudes" do jogador/ homem brasileiro. Nota-se aqui um retorno ao elemento discursivo que fora caracterizador da identidade nacional nas décadas anteriores: a miscigenação. Acredita-se que a exaltação à mistura étnica contribuía ao sentimento de pertença, estreitando laços identitários e fortalecendo uma torcida favorável ao selecionado. Ao mesmo tempo, o bom

\footnotetext{
${ }^{48}$ De acordo com Freitas Junior (2014), tratava-se de "um projeto intervencionista de cunho civilizatório, composto por 96 artigos, dos quais os primeiros 63 eram relativos aos procedimentos administrativos que envolviam a Confederação Brasileira de Desportos (CBD), o Conselho Nacional de Desportos (CND), o Conselho Técnico de Futebol (CTF), bem como detalhava as atribuições de cada membro da comissão técnica, detalhes das convocações e obrigações das equipes que tivessem jogadores convocados e as funções do capitão da equipe" (FREITAS JUNIOR, 2014, p.04). Para este autor, a eficácia desta iniciativa foi proveniente de um conjunto de medidas voltadas para os aspectos técnicos, físicos, psíquicos, sociais e culturais do selecionado brasileiro.

${ }^{49}$ Para Freitas Junior (2009), "os literatos desprezavam o projeto modernizador implantado no selecionado nacional, não realizando nenhum comentário sobre ele" (FREITAS JUNIOR, 2009, p.122).
}

desempenho da seleção na primeira fase desta Copa contribuiu à recuperação da autoestima da população frente ao cenário internacional. Se o Brasil era capaz de vencer o mundial, talvez a nação fosse capaz de vencer o subdesenvolvimento...

A respeito da representação do Brasil às demais nações, por meio do futebol, o comportamento dos jogadores dentro e fora do campo foi elogiado, por jornalistas nacionais e internacionais. De acordo com o presidente da comissão de arbitragem da FIFA,

Os brasileiros merecem ganhar este campeonato. (...) sua conduta foi exemplar no campo da prática esportiva e fora dele, cativando os habitantes de Hindas, onde ficaram concentrados durante a realização do torneio. [...] eles foram sempre obedientes com os juízes a ponto de jamais contestarem qualquer decisão ${ }^{50}$.

Apesar deste tipo de reconhecimento, não houve por parte do JS publicações associando este bom comportamento às ações do PPMC. E, ao contrário de incentivar o trabalho coletivo, que já era presente na atuação futebolística dos países europeus, o JS publicou sobre a genialidade, a capacidade criativa e o futebol-arte, característicos da identidade brasileira - que, segundo os cronistas, teriam sido fundamentais para que o Brasil chegasse às finais do Mundial de Futebol de 1958.

Evitando incorrer nos mesmos erros, os cronistas retomam frequentemente a derrota de 1954 como um acontecimento traumático, porém pedagógico, que serviu para o amadurecimento do homem brasileiro ${ }^{51}$. Em seus escritos, tendo como exemplo 1950, versavam sobre a necessidade de que pessoas de fora não se envolvessem na organização do selecionado e que os jogadores fizessem aquilo que sabiam e faziam muito bem ${ }^{52}$. Assim, a esperança de colocar-se mundialmente foi consagrada com a vitória brasileira na Copa da Suécia, contra seus anfitriões: "então veio do dia 15 de junho de 1958, a data da redenção do futebol brasileiro - redenção da derrota de 1950, redenção das suas possibilidades nacionais (...) redenção da arte contra a técnica" (GUTERMAN, 2014, p.126).

\footnotetext{
${ }^{50}$ ROUS, Stanley. Prefácio. In: ESCARTIN, Pedro. Apoteose ao Brasil Tradução Tito Leite. Rio de Janeiro: Monterrey, 1959, p.09.10.

${ }^{51}$ RODRIGUES FILHO, Mario. Faltam apenas dois dias. Jornal dos Sports: Rio de Janeiro, 27 de junho de 1958, p.05.

${ }^{52}$ RODRIGUES FILHO, Mario. Vemos deixar o scratch ser campeão do mundo. Jornal dos Sports: Rio de Janeiro, 17 de junho de 1958, p.05
} 
Mario Filho, em "Palavras aos jogadores brasileiros" atribuiu a vitória à dedicação, ao amor, à pátria, ao entusiasmo e à técnica, qualidades que seriam características naturais dos brasileiros:

Vocês estão longe, jogadores do Brasil, e não vão me escutar. Mas todos nós sentimos a necessidade de dizer alguma coisa ou de exprimir alguma coisa. $\mathrm{O}$ que eu queria dizer a vocês era muito obrigado. Sempre temíamos uma prova como a que vocês venceram. Não se tratava apenas de uma herança de 16 de julho. Mas, em 16 de julho de 50, não foi apenas um escrete brasileiro que perdeu. Sentimos mais a derrota, porque era também a nossa derrota. Faltava-nos alguma coisa para uma conquista tão grande. (...) Por isso, toda vez que um escrete brasileiro ia para um Campeonato do Mundo, tínhamos maior medo das nossas falhas do que confiança nas nossas virtudes. Não bastava ter o melhor futebol, que tínhamos, para sermos campeões do mundo (...) Somos brasileiros e isto basta. Já não haverá brasileiros que, como em 16 de julho, se lamentavam de ser brasileiros. Nunca se negou tanto o Brasil como em 16 de Julho. Porque aquele escrete de 50 resumia as nossas virtudes e defeitos. Esquecemos as virtudes que tínhamos para lastimar os defeitos que tinham nos tirado um campeonato do mundo. Vocês aí na Suécia, só exibiram e só exaltaram as nossas virtudes. Mostraram até onde o brasileiro pode ir, pela dedicação, entusiasmo, pelo amor a pátria, pelo vigor atlético, pela disciplina e pela técnica... Duvida-se do futebol brasileiro, duvidando-se do Brasil. E vocês varreram essa dúvida, exaltaram o Brasil perante o mundo. Não somos apenas brilhantes, não somos apenas malabaristas, não somos apenas artistas de circo: somos campeões do mundo. (...) porque tivemos o melhor futebol do mundo. Muito obrigado, jogadores brasileiros: vocês mostraram ao mundo um Brasil perfeito ${ }^{53}$.

Neste excerto é possível observar a reiteração da Copa de 1950, como se a vitória em 1958 fosse a redenção brasileira em relação às suas questões identitárias. Esse "Brasil perfeito" reavivou o sentimento de pertencimento nacional. Em comemoração à grande vitória, dentro e fora do campo, novos símbolos identitários atrelados ao futebol foram se formando e legitimando esta relação ${ }^{54}$. Finalmente o futebol,

\footnotetext{
53 RODRIGUES FILHO, Mario. Palavras aos jogadores brasileiros. Jornal dos Sports: Rio de Janeiro, 30 de junho de 1958, p.01 e 05.

${ }^{54}$ A título de exemplo, é possível citar a composição "A taça do mundo é nossa", escrita por Wagner Maugeri, Lauro Müller, Maugeri Sobrinho e Victor Dagô.
}

um dos elementos constituintes do "ser brasileiro", mostrava ao mundo as potencialidades do país.

\section{CONSIDERAÇÕES FINAIS}

O que se observa na trajetória das Copas do Mundo de Futebol da década de 1950 é uma relação estreita entre o contexto político, jornalismo identidade e futebol. O estudo histórico da intersecção entre estes campos permite compreender que a valorização do JS a uma vitória ou derrota na Copa estava relacionado ao contexto político mais amplo, tensionado pelas ideologias e paixões dos cronistas - que, em última (ou primeira?) instância, eram também torcedores.

Ao longo da década de 1950 diferentes governos e projetos identitários perpassaram a sociedade brasileira. Por sua vez, diferentes foram as estratégias narrativas adotadas pelos cronistas do $J S$ em relação ao pertencimento e o futebol. Em momentos em que a política estava forte e organizada sob um projeto nacionalista, os cronistas - tal qual seus leitores, mas com discurso autorizado - encontravam-se imersos em uma atmosfera que valorizavam determinados preceitos e reafirmavam o futebol enquanto elemento característico da "brasilidade". Esta identidade construída, que valorizava a cultura nacional a partir de sua diversidade étnica (democracia racial), encheu a população de otimismo em relação à Copa do Mundo de 1950, sediada em casa. Esperava-se mostrar ao mundo, através da organização do campeonato e da vitória no futebol, a pujança nacional. Postas estas questões, acredita-se que esta derrota tenha sido marcante por frustrar as expectativas nacionalistas, fomentadas pelas crônicas esportivas.

Outra derrota, que não recebeu o mesmo relevo, foi no campeonato mundial de 1954. Acredita-se que este fracasso não configurou um "trauma" por uma série de motivos, da qual destaca-se: a) as estruturas identitárias e o projeto de nação já vinham abalados desde 1950 e asseveraram-se com a instabilidade econômica do período; b) ao mesmo tempo, os meios de comunicação, com destaque para o Jornal dos Sports, constantemente retomavam a Copa anterior como referente nas crônicas em 1954, tornando a derrota de 1950 um trauma que por sua constante enunciação ficou gravado no imaginário popular ${ }^{55}$.

\footnotetext{
${ }^{55}$ Em menor proporção, acredita-se que o posicionamento "neutro" adotado
} 
Já a vitória na Copa do Mundo de 1958 ocorreu em um momento em que as condições políticas e econômicas estavam se transformado. O nacional-desenvolvimentismo trouxe novamente aos brasileiros a segurança de si. Ao mesmo tempo, aquele antigo projeto de identidade nacional, atrelado ao futebol e a miscigenação, ganhou novo fôlego com a presença de Garrincha e Pelé no selecionado. Neste contexto do qual o $J S$ partilhava sentidos, os cronistas escreviam sobre a necessidade de os brasileiros deixarem o passado para trás, valorizando-se. Por meio destes discursos, compreendia-se que com a vitória no mundial seria possível conquistar novos capitais e mudar sua representação no cenário internacional e de vez acabar com o "complexo de vira-latas"

Com análise das crônicas do $J S$, na perspectiva da intersecção entre política, jornalismo, identidade e futebol, foi possível perceber que determinadas considerações contemporâneas sobre as Copas realizadas na década de 1950 estão relacionadas - entre outros motivos a serem investigados - ao imaginário construído por estas publicações, que foram passando de geração em geração como uma herança. Segundo Pollak (1992), existem alguns elementos que são constitutivos da memória, dos quais destaca-se para esta problematização os acontecimentos "vividos por tabela", ou seja, aqueles acontecimentos nem sempre vividos pela pessoa, mas pelo grupo com o qual se identifica e que no imaginário coletivo tomaram grande relevo. Assim, "é perfeitamente possível que, por meio da socialização política, ou da socialização histórica, ocorra um fenômeno de projeção ou de identificação com determinado passado, tão forte que podemos falar numa memória quase herdada" (POLLAK, 1992, p.02).

A esse respeito, ainda hoje é possível observar que praticamente não existem estudos e/ou livros que tratem da participação brasileira na Copa do Mundo de 1954 (FREITAS JUNIOR, 2009). Em contrapartida, para além de trabalhos acadêmicos, a "derrota de 50" é popularmente conhecida, tanto ou mais que primeira vitória brasileira no mundial, em 1958. Acredita-se que isto ocorre porque, além do

pelo Jornal dos Sports em relação aos jogos que antecederam a Copa de 1954 contribuiu para uma menor visibilidade desta em detrimento de outros mundiais de futebol que o Brasil participou.

${ }^{56}$ RODRIGUES, Nelson Falcão. A humilhação. Revista Manchete Esportiva: Rio de Janeiro, 5 de maio de1956. fato de existirem acontecimentos que marcam tanto determinado grupo que sua memória irá por muito tempo transmitir determinado sentido com alto grau de identificação (POLLAK, 1992), houve um trabalho de enquadramento de memória por parte dos historiadores e instituições sociais, incluindo a própria imprensa, realizado posteriormente aos eventos. E agora "quando vemos esses pontos de referência de uma época longínqua, frequentemente, os integramos em nossos próprios sentimentos de filiação e de origem, de modo que certos elementos são progressivamente integrados num fundo cultural comum a toda humanidade" (POLLAK, 1989, p. 11)

\section{REFERÊNCIAS}

BARBOSA, Marialva Carlos. Meios de comunicação e história: um universo de possíveis. In: RIBEIRO; FERREIRA. Mídia e memória: a produção de sentidos nos meios de comunicação. Rio de Janeiro: Mauad X, 2007.

BARBOSA, Marialva. História Cultural da Imprensa Brasil 1900 - 2000. Rio de Janeiro: Mauad X, 2007.

CANDIDO, Antonio (et. al). A Crônica. Campinas: Ed. da Unicamp, 1992.

CAPRARO, André; SANTOS, Natasha; LISE, Riqueldi. O enredo da vitória - Seleção brasileira de futebol e identidade nacional (1950-1970). Record: Revista de História do Esporte. Vol.5, n.2, julho-dezembro de 2012.

CHARTIER, Roger. A História Cultural: entre práticas e representações. Rio de Janeiro: DIFEL, 1990.

CHAUÍ, Marilena. O Discurso competente. In: CHAUí, Marilena. Cultura e Democracia. São Paulo: Cortez, 1989.

COUTO. André Alexandre Guimarães. Cronistas esportivos em campo: letras, imprensa e cultura no Jornal dos Sports (1950-1958). (Tese) Departamento de História, Universidade Federal do Paraná, Curitiba, 2016.

DAMATTA, Roberto (org.). Universo do Futebol: esporte e sociedade brasileira. Rio de Janeiro: Pinakotheke, 1982.

DURKHEIM, Émile. Da divisão do trabalho social. Lisboa: Editorial Presença, 1989.

FAUSTO, Boris. História do Brasil. São Paulo: Editora da Universidade de São Paulo, 2015.

FAUSTO NETO, Antônio. Contratos de leitura: entre regulações e deslocamentos. In: Diálogos Possíveis Revista da Faculdade Social da Bahia. Ano 6, n.2 (jul./ dez) Salvador: FSBA, 2007.

FREITAS JUNIOR, Miguel Archanjo de. No meio do caminho: tensões presentes nas representações sobre o 
futebol e o ideal de modernidade brasileira na década de 1950. (Tese) Departamento de História, Universidade Federal do Paraná, Curitiba, 2009.

Plano Paulo Machado de Carvalho: um projeto modernizador ou uma tentativa de civilizar os jogadores brasileiros? Recorde: Revista de História do Esporte Artigo Volume 7, número 1, janeiro-junho de 2014, p. 1-33.

GUTERMAN, Marcos. O futebol explica o Brasil: uma história da maior expressão popular do país. São Paulo: Contexto, 2014.

LOPES, Fernanda Lima. Identidade jornalística e memória. In: RIBEIRO; FERREIRA. Mídia e memória: a produção de sentidos nos meios de comunicação. Rio de Janeiro: Mauad X, 2007.

MELO, Isabelle Anchieta de. A defesa de uma nova objetividade jornalística: a intersubjetividade. BOCC. Biblioteca On-line de Ciências da Comunicação, v. 01, p. 07, 2007. Disponível em: http://www.bocc.ubi.pt/pag/meloisabelle-intersubjectividade.pdf. Acesso em: 18.06.2017.

NEGREIROS, Plínio José Labriola de Campos. Futebol nos anos 1930 e 1940: construindo a identidade nacional. História: questões \& debates. Curitiba, PR. UFPR, ano 20, n 39, jul/dez. 2003. p.150.

PARADA, Maurício. A ordem da memória: a imprensa e o imaginário político do Estado Novo. RIBEIRO; FERREIRA. Mídia e memória: a produção de sentidos nos meios de comunicação. Rio de Janeiro: Mauad X, 2007.

POLLAK, Michael. Memória e Identidade Social. In: Estudos Históricos, Rio de Janeiro, vol.5, n.10, 1992.

RIBEIRO, Luiz Carlos. A crônica esportiva como fonte para o estudo histórico. In: FREITAS JUNIOR; CAPRARO. Passe de Letra: crônica esportiva e sociedade brasileira. Ponta Grossa: Editora Vila Velha, 2012.

. Brasil: futebol e identidade nacional. EFDeports Revista Digital - Buenos Aires - Ano 8 - No56 - Janeiro de 2003.

RIBEIRO; FERREIRA. Mídia e memória: a produção de sentidos nos meios de comunicação. Rio de Janeiro: Mauad X, 2007.

SANTOS, Regina Maria dos. O jornal como lugar de memória: um debate sobre memória coletiva e a aceleração do tempo. OPSIS, Revista do Niesc, V.2, N.2 Jul/Dez de 2002. 